Article

\title{
Spatial and Temporal Calcium Signaling and Its Physiological Effects in Moso Bamboo under Drought Stress
}

\author{
Xiong Jing, Chunju Cai *, Shaohui Fan, Lujun Wang and Xianli Zeng \\ International Center for Bamboo and Rattan, State Forestry and Grassland Administration Key Laboratory of \\ Bamboo and Rattan, Beijing 100102, China; jxicbr@163.com (X.J.); fansh@icbr.ac.cn (S.F.); \\ wuatang@icbr.ac.cn (L.W.); zengxl723@163.com (X.Z.) \\ * Correspondence: caicj@icbr.ac.cn; Tel.: +86-010-8478-9806
}

Received: 25 January 2019; Accepted: 22 February 2019; Published: 2 March 2019

check for updates

\begin{abstract}
Elevations in cytosolic free calcium concentration constitute a fundamental signal transduction mechanism in plants; however, the particular characteristics of calcium ion $\left(\mathrm{Ca}^{2+}\right)$ signal occurrence in plants is still under debate. Little is known about how stimulus-specific $\mathrm{Ca}^{2+}$ signal fluctuations are generated. Therefore, we investigated the identity of the $\mathrm{Ca}^{2+}$ signal generation pathways, influencing factors, and the effects of the signaling network under drought stress on Phyllostachys edulis (Carrière) J. Houz. Non-invasive micro testing and laser confocal microscopy technology were used as platforms to detect and record $\mathrm{Ca}^{2+}$ signaling in live root tip and leaf cells of P. edulis under drought stress. We found that $\mathrm{Ca}^{2+}$ signal intensity (absorption capacity) positively correlated with degree of drought stress in the P. edulis shoots, and that $\mathrm{Ca}^{2+}$ signals in different parts of the root tip of P. edulis were different when emitted in response to drought stress. This difference was reflected in the $\mathrm{Ca}^{2+}$ flux and in regional distribution of $\mathrm{Ca}^{2+}$. Extracellular $\mathrm{Ca}^{2+}$ transport requires the involvement of the plasma membrane $\mathrm{Ca}^{2+}$ channels, while abscisic acid (ABA) can activate the plasma membrane $\mathrm{Ca}^{2+}$ channels. Additionally, $\mathrm{Ca}^{2+}$ acted as the upstream signal of $\mathrm{H}_{2} \mathrm{O}_{2}$ in the signaling network of P. edulis under drought stress. $\mathrm{Ca}^{2+}$ was also involved in the signal transduction process of ABA, and ABA can promote the production of $\mathrm{Ca}^{2+}$ signals in P. edulis leaves. Our findings revealed the physiological role of $\mathrm{Ca}^{2+}$ in drought resistance of $P$. edulis. This study establishes a theoretical foundation for research on the response to $\mathrm{Ca}^{2+}$ signaling in P. edulis.
\end{abstract}

Keywords: $\mathrm{Ca}^{2+}$ signal; drought stress; living cell; Moso Bamboo (Phyllostachys edulis); plasma membrane $\mathrm{Ca}^{2+}$ channels; signal network

\section{Introduction}

Calcium ions $\left(\mathrm{Ca}^{2+}\right)$ are a primary signaling element for diverse cell processes in response to environmental cues. $\mathrm{Ca}^{2+}$ is a vital regulatory molecule for response to stress in plant growth and development [1,2]. When plants are affected by various physical stimuli, such as temperature, drought, salt, light, gravity, or chemical substances, such as plant hormones and pathogenic inducers, extracellular and intracellular sources of calcium release $\mathrm{Ca}^{2+}$ into the cytoplasm through $\mathrm{Ca}^{2+}$ channels. The spatio-temporal activity of membrane-localized $\mathrm{Ca}^{2+}$ channels or transporters causes an increase in cytosolic free calcium ion concentration $\left(\mathrm{Ca}^{2+}\right) \mathrm{cyt}$, resulting in specific signals [3,4]. Almost all of the extracellular stimuli can lead to changes in intracellular $\left(\mathrm{Ca}^{2+}\right)$ cyt. However, different stress stimuli can lead to variations in the pattern of $\mathrm{Ca}^{2+}$ spatial-temporal changes. There are significant differences in time, frequency, amplitude, and regional distribution. Studies have illustrated that plants may rely on different forms of $\mathrm{Ca}^{2+}$ to reflect the specificity of different stimulation signals to achieve signal transduction [5]. 
Although $\mathrm{Ca}^{2+}$ signaling has been extensively studied in other gramineous plants, such as rice, little is known about the $\mathrm{Ca}^{2+}$ signal identities and functions of the clonal plant Phyllostachys edulis (Carrière) J. Houz. Therefore, a better understanding of the calcium signal characteristics of bamboo under drought stress is an important prerequisite for the study of clonal habits of bamboo using signal transduction methods.

At present, research has shown that root tip cells of P. edulis seedlings transport $\mathrm{Ca}^{2+}$ from the extracellular region, cell walls, nucleus, and other calcium stores under drought stress. With increased duration of drought stress, the distribution of and changes in $\mathrm{Ca}^{2+}$ will produce regular fluctuations [6]. The more pronounced the drought stress, the greater the $\mathrm{Ca}^{2+}$ distribution in the root tip. Exogenous application of calcium fertilizer can relieve the physiological effects of drought stress and improve drought resistance in P. edulis [7]. Although roots constitute the most direct organ of water absorption, both $\mathrm{Ca}^{2+}$ uptake velocity and density of the different organ changed under drought stress [8]. Moreover, stomatal opening and closing behaviors were also regulated by $\mathrm{Ca}^{2+}$ signals at the cellular scale [9].

When there are no environmental pressures present, the majority of the $\mathrm{Ca}^{2+}$ in plant cells is distributed in the extracellular compartments, cell wall, vacuoles, and endoplasmic reticulum, with less concentrated distribution in the cytoplasm to prevent the precipitation of calcium and phosphoric acid [10]. To regulate this lower $\mathrm{Ca}^{2+}$ concentration in the cytoplasm, plant cells will actively export $\mathrm{Ca}^{2+}$. When a stimulus signal reaches a cell, plasma $\mathrm{Ca}^{2+}$ channels transiently increase $\mathrm{Ca}^{2+}$ permeability. When the cytoplasmic $\mathrm{Ca}^{2+}$ concentration increases to a certain threshold, it binds to calmodulin (CaM) to form Ca-CaM compounds, and thus activate CaM. Activated CaM further activates various key enzymes in the plant, which further phosphorylates and dephosphorylates phospholipase, nicotinamide adenine dinucleotide (NAD) kinase, and $\mathrm{Ca}^{2+}$-ATPase. In addition, it amplifies the initial stimulation signal and subsequently causes the cells to produce a physiological response corresponding to the signal, such as cell division, material synthesis, etc. [2,11].

Under drought stress, a complex signaling network is formed by a communication mechanism between regulatory signals. $\mathrm{Ca}^{2+}$ signaling can be combined with calcium receptors, such as $\mathrm{CaM}$, to amplify the signal and transmit the oscillation to initiate stomatal closure and production of reactive oxygen species $[12,13]$. Previously, reactive oxygen species were considered toxic byproducts of plant metabolism. However, recent studies have shown that reactive oxygen species also have an important part to play in cellular signal transduction and regulation networks [14-16]. Abscisic acid (ABA) is a root chemical signal that plays an important role in regulating stomatal movement of plants under drought stress. $\mathrm{H}_{2} \mathrm{O}_{2}$ can be used as a downstream signal of $\mathrm{ABA}$ to activate $\mathrm{Ca}^{2+}$ channels in the plasma membrane. Involvement of ABA can induce stomatal closure by increasing $\mathrm{Ca}^{2+}$ concentration in guard cells [17]. Sha et al. used 25\% PEG-6000 to simulate water stress in maize plants, inducing CaM gene expression in the leaves [18]. The study found that exogenous ABA treatment can also induce significant $\mathrm{CaM}$ gene expression, and that $\mathrm{H}_{2} \mathrm{O}_{2}$ is involved in ABA-induced CaM gene expression in the late regulation period.

The emergence of new technologies has made it possible to study changes in $\mathrm{Ca}^{2+}$ signaling in response to environmental stress in plants. Non-invasive microelectrode technology (NMT) and laser confocal microscopy are effective techniques for detecting $\mathrm{Ca}^{2+}$ signals. Antoine et al. demonstrated the influx of $\mathrm{Ca}^{2+}$ over the course of fertilization in maize with non-invasive microelectrode technology [19]. In addition, a live-cell $\mathrm{Ca}^{2+}$ imaging platform has been used to detect $\mathrm{Ca}^{2+}$ signals in the cytoplasm and nucleus of Arabidopsis thaliana (L.) Heynh. This technique was also used to observe the spatial-temporal distribution of $\mathrm{Ca}^{2+}$ in living cells of $A$. thaliana under stimulated adverse environmental conditions [20]. These studies use a method to generate $\mathrm{Ca}^{2+}$ signaling pathways by treating experimental materials with $\mathrm{Ca}^{2+}$ inhibitors. Ethylene glycol-bis (2-aminoethylether)-N, $\mathrm{N}, \mathrm{N}^{\prime}, \mathrm{N}^{\prime}$-tetraacetic acid (EGTA), lanthanum chloride $\left(\mathrm{LaCl}_{3}\right)$, and chlorpromazine $(\mathrm{CPZ})$ are the most commonly used reagents. At present, laser confocal scanning microscopy has been used to study $\mathrm{Ca}^{2+}$ fluorescence localization in P. edulis cells under drought stress; however, most of these studies have been limited to the root tip [7] 
and few studies have been conducted on $\mathrm{Ca}^{2+}$ localization in cells located in the leaves of P. edulis using this technique.

To bridge this scientific gap, in this study we investigated the spatial-temporal location and flux velocity of $\mathrm{Ca}^{2+}$ ions by inducing drought stress in P. edulis with 20\% PEG-6000. Using non-invasive micro-test technology (NMT) and laser confocal microscopy, we demonstrated the regularity of cellular $\mathrm{Ca}^{2+}$ dynamics in response to drought stress and provided measures of $\mathrm{Ca}^{2+}$ signaling in P. edulis leaf cells. We further studied the $\mathrm{Ca}^{2+}$ signaling pathway and analyzed the communication of the signal network pathway between $\mathrm{Ca}^{2+}, \mathrm{H}_{2} \mathrm{O}_{2}$, and $\mathrm{ABA}$ in leaf cells using $\mathrm{Ca}^{2+}$ inhibitors $\left(\mathrm{Ca}^{2+}\right.$ channel blockers) and ABA. The aim of this study was to reveal the physiological role of $\mathrm{Ca}^{2+}$ in drought resistance and establish a theoretical foundation for the cellular response to $\mathrm{Ca}^{2+}$ signaling in P. edulis.

\section{Materials and Methods}

\subsection{Plant Materials and Treatment}

The sprouting seed materials used in this study were taken from the parent P. edulis from Guilin, Guangxi in September 2017. The thousand seed weight of these seed materials is equal to $22.75 \pm 0.35 \mathrm{~g}$. The $P$. edulis seeds were treated in November 2017. The seeds were soaked in warm water for $24 \mathrm{~h}$ at $50{ }^{\circ} \mathrm{C}$, and then removed and disinfected with $5 \%$ potassium permanganate solution for 5 min. The sterilized seeds were then repeatedly washed with distilled water and germinated in an incubator in a dark environment set to a constant temperature of $25^{\circ} \mathrm{C}$. After the seeds germinated, the seedlings were selected for regular, even growth and placed in a Petri dish with pad disinfectant (lower layer) and filter paper (upper layer). The dishes were cultured at a constant temperature of $28{ }^{\circ} \mathrm{C}$ in an illumination incubator (PRX-1000B, Safe, Ningbo, China). The Petri dishes were set to point the roots vertically downwards. Proper humidity was maintained in the Petri dishes and any seeds found to be growing mold were removed. When the vertical root length reached approximately $3 \mathrm{~cm}$, the seedlings were transferred to a Seed Germination Pouch (Phytotc CYG-98LB, size: $30 \mathrm{~cm} \times 25 \mathrm{~cm}$, Beijing Bioconsumable Tech., Ltd., Beijing, China) and cultured with a 12-h light period with a light intensity of $120-150 \mathrm{mmol} \mathrm{m}^{-2} \mathrm{~s}^{-1}$ and a temperature of $22 \pm 2{ }^{\circ} \mathrm{C}$. Figure 1 gives more details about the performance of the experimental materials.
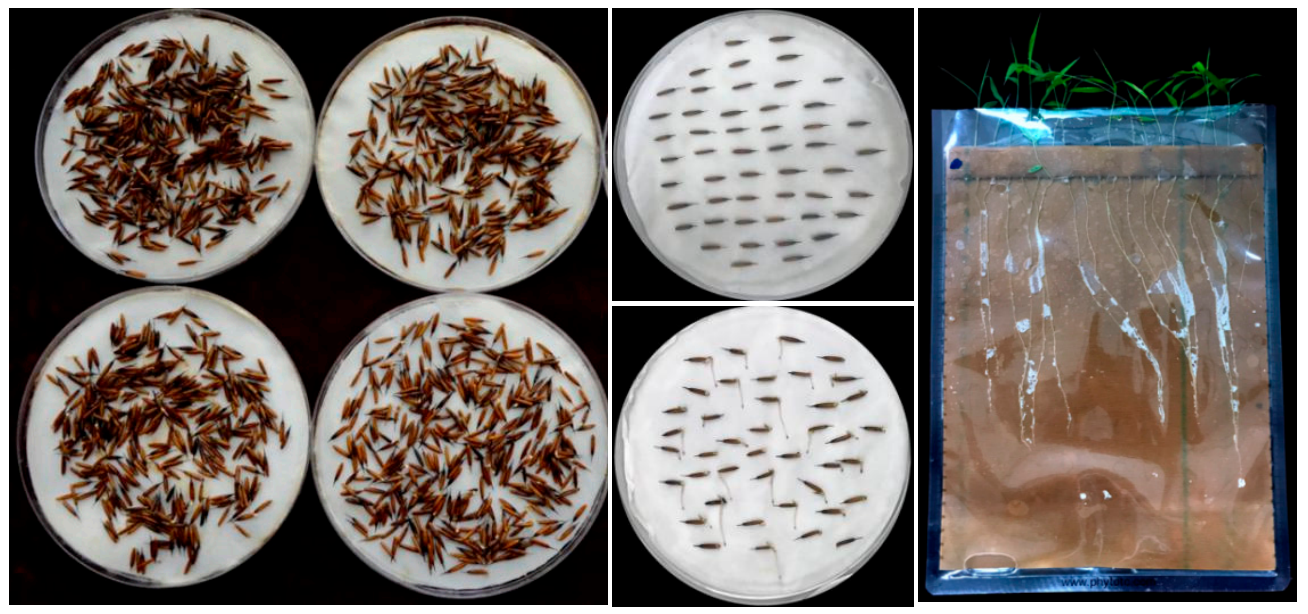

Figure 1. Cultivation of $P$. edulis sprouting seedlings.

For each experimental treatment, ten strains of $P$. edulis seedlings were selected in duplicate. To substitute drought stress, 20\% polyethylene glycol-6000 (PEG, Coolaber, Beijing, China) was used for $5 \mathrm{~min}, 10 \mathrm{~min}, 15 \mathrm{~min}$, and $30 \mathrm{~min}$. Distilled water was used for the control (CK). In addition, $\mathrm{Ca}^{2+}$ inhibitors and ABA (Sigma-Aldrich, Shanghai, China) were used to treat P. edulis seedlings. The $\mathrm{Ca}^{2+}$ production pathway and its distribution were studied, and the effects of $\mathrm{Ca}^{2+}$ signaling on the $\mathrm{H}_{2} \mathrm{O}_{2} / \mathrm{ABA}$ signaling network were analyzed under drought stress. The $\mathrm{Ca}^{2+}$ inhibitors used in 
the experiment were extracellular $\mathrm{Ca}^{2+}$ chelating agent EGTA, $\mathrm{Ca}^{2+}$ channel blocker $\mathrm{LaCl}_{3}$, and $\mathrm{CaM}$ antagonist CPZ (Sigma-Aldrich, Shanghai, China). The dosage of additives was added according to the method of $\mathrm{Lu}[21]$.

\subsection{Laser Confocal Microscopy Luminescence Imaging}

Here, we present detailed instructions for laser confocal microscopy luminescence imaging of cytosolic $\mathrm{Ca}^{2+}$ and $\mathrm{H}_{2} \mathrm{O}_{2}$ concentration and distribution in root tip and leaf cells of P. edulis seedlings.

\subsubsection{Esterified Fluorescent Probe Stock Solution Configuration}

The calcium ion fluorescent probe Fluo-8 (AAT Bioquest, Sunnyvale, CA, USA) was fully dissolved in dimethyl sulfoxide (DMSO, Sigma-Aldrich, Shanghai, China) to a concentration of $1 \mathrm{mmol} / \mathrm{L}$, $-20{ }^{\circ} \mathrm{C}$ dark storage reserve.

$2^{\prime}, 7^{\prime}$-dichloro fluorescin diacetate (H2DCFDA, Sigma-Aldrich, Shanghai, China) was made up of $50 \mathrm{mmol} / \mathrm{L}$ DMSO mother liquor, which was stored in a separate container and frozen.

\subsubsection{Fluorescent Labeling}

As to the root tip cells and leaf cells $\mathrm{Ca}^{2+}$ fluorescent labeling, we put the lower epidermis of the leaves of $P$. edulis seedlings flat on transparent tape and used a surgical blade to gently scrape the upper epidermis off the leaves. Then we placed the samples of lower epidermis in Hank's balanced salt solution (without calcium ions) containing $20 \mu \mathrm{mol} / \mathrm{L}$ Fluo- 8 . We incubated them for $40 \mathrm{~min}$ in the dark at room temperature and rinsed the lower epidermis of $P$. edulis leaves with a buffer several times. We then incubated them again at room temperature for $20 \mathrm{~min}$, ensuring that the esterification probe was fully dissolved. Finally we placed them on a glass slide and added $0.5 \mathrm{~mL}$ of Hank's buffer to complete slice preparation.

As to the $\mathrm{H}_{2} \mathrm{O}_{2}$ fluorescent labeling of P. edulis leaf cells, the lower epidermis of P. edulis seedling leaves was first laid flat on transparent tape, and then the upper epidermis of the leaves was removed using a surgical blade and placed in MES, Free acid, monohydrate (Coolaber, Beijing, China) buffer to a final concentration of $50 \mu \mathrm{mol} / \mathrm{L}$ and incubated at room temperature in the dark for $15 \mathrm{~min}$. We rinsed the lower epidermis samples several times with a buffer and placed them on glass slides. We then added $0.5 \mathrm{~mL}$ of buffer to complete slice preparation.

\subsubsection{Laser Confocal Microscope Observation}

Localization of $\mathrm{Ca}^{2+}$ fluorescence in P. edulis root tips and leaves: The prepared in vivo test slices were placed on a laser confocal microscope (LSM510, LeicaDM4, Berlin, Germany) for observation and scanning. Fluorescence intensity was controlled and all parameters were kept constant during the test (parameter settings: excitation wavelength 488 nm, BP 505-530, Pinhole 280, DG 581, AO 0.1, AG 1.34). At least three fields from different repeats were selected for each test. After the results were stable, one field of view was used for the analysis.

Localization of $\mathrm{H}_{2} \mathrm{O}_{2}$ fluorescence in root tips and leaves of $P$. edulis: The prepared in vivo test slices were placed on a laser confocal microscope (LSM510) for observation and scanning (parameter settings: excitation wavelength 488 nm, BP 505-530, Pinhole 386, DG 768, AO 0, AG 1). At least three fields from different repeats were selected for each test. After the results were stable, one field of view was used for analysis.

\subsection{Measurement of $\mathrm{Ca}^{2+}$ Flux}

$\mathrm{Net} \mathrm{Ca}^{2+}$ flux was measured using non-invasive micro-test technology (Physiolyzer, Younger USA LLC, Amherst, MA 01002, USA; Xuyue (Beijing) Sci. \& Tech. Co., Ltd., Beijing, China). NMT non-invasively measures $\mathrm{Ca}^{2+}$ fluxes with a high temporal and spatial resolution. It measures 
the concentration gradient of $\mathrm{Ca}^{2+}$ by means of selective microsensor oscillation between two points in the root tip of $P$. edulis seedlings (Figure 2).

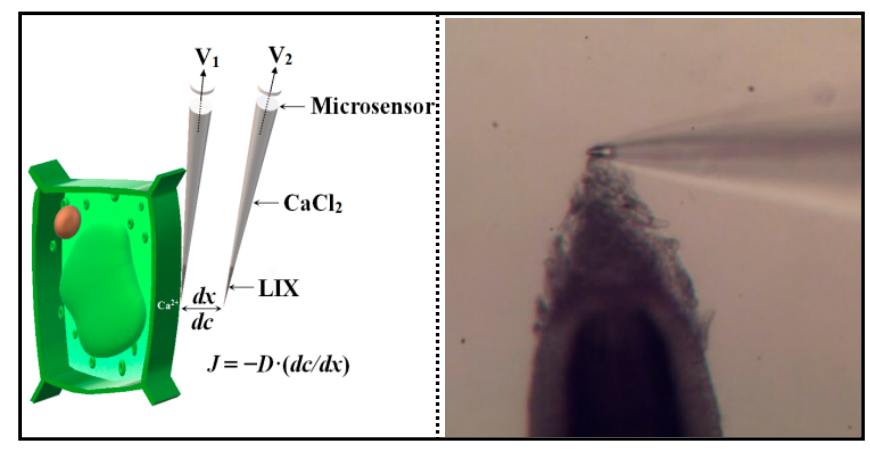

Figure 2. Schematic diagram and measured photo of $\mathrm{Ca}^{2+}$ flux analysis by non-invasive micro-tests. The diagram is to demonstrate the principles behind NMT testing and is not to scale. The tip diameter of the microsensor is about $5 \mu \mathrm{m}$.

After different test treatments, the roots were rinsed with redistilled water and immediately incubated in measuring solution to equilibrate for $10 \mathrm{~min}$. Then, the roots were transferred to a measuring chamber containing $10-15 \mathrm{~mL}$ of a fresh measuring solution. Ions were monitored in the following solutions: $0.1 \mathrm{mM} \mathrm{KCl}, 0.1 \mathrm{mM} \mathrm{CaCl} 2,0.1 \mathrm{mM} \mathrm{MgCl}, 0.5 \mathrm{mM} \mathrm{NaCl}, 0.3 \mathrm{mM} \mathrm{MES}$, and $0.2 \mathrm{mM} \mathrm{Na}_{2} \mathrm{SO}_{4}$, following adjustment of the $\mathrm{pH}$ to 6.0. The measuring chamber was mounted on the micromanipulator, and the flux microsensor was positioned close to the root tip at four points: at the pileorhiza, meristematic zone, elongation zone, and mature zone $(0 \mu \mathrm{m}, 200 \mu \mathrm{m}, 500 \mu \mathrm{m}$, and $800 \mu \mathrm{m}$ from the root apex) of $P$. edulis seedlings.

The system setup parameters in the experiment are as follows. The $\mathrm{Ca}^{2+}$ flux microsensor ( $\Phi 4.5 \pm 0.5 \mu \mathrm{m}, \mathrm{XY}$-CGQ-01, Xuyue (Beijing) Sci. \&Tech. Co., Ltd., Beijing, China) was filled with a backfilling solution $\left(100 \mathrm{mM} \mathrm{CaCl}_{2}\right)$ to a length of approximately $1.0 \mathrm{~cm}$ from the tip. The micropipettes were front filled with 40-50 $\mu \mathrm{m}$ columns of selective liquid ion-exchange cocktails $\left(\mathrm{Ca}^{2+} \mathrm{LIX}, \mathrm{XY}-\mathrm{SJ}-\mathrm{Ca}\right.$, YoungerUSA LLC, Amherst, MA, USA). An Ag/AgCl wire microsensor holder YG003-Y11 (Younger USA) was inserted in the back of the microsensor to make electrical contact with the electrolyte solution. YG003-Y11 (Younger USA) was used as the reference microsensor. Prior to the flux measurement, the flux microsensor was calibrated with a measuring solution having different concentrations of $\mathrm{Ca}^{2+}$ $0.1 \mathrm{mM}$ and $0.01 \mathrm{mM}$. The electrodes with a Nernstian slope $>22 \mathrm{mV}$ per decade were used in this study. Only the same flux microsensor was calibrated again according to the same procedure and standards after each test. Data was discarded if the post-test calibrations failed. The following figure shows the schematic and actual measurement of $\mathrm{Ca}^{2+}$ flux.

The data for $\mathrm{Ca}^{2+}$ fluxes were calculated by Fick's law of diffusion as follows:

$$
J=-D \cdot(d c / d x)
$$

where $d x(30 \mu \mathrm{m})$ is the distance the flux microsensor moved repeatedly from one point to another perpendicular to the surfaces of the samples at a frequency of ca. $0.3 \mathrm{~Hz}$.

\subsection{Statistical Analysis}

Data were analyzed by single factorial analysis of variance and statistical correlation analysis. The significance of differences among means was evaluated using the least significant difference test, with a family wise error rate of 0.05, using the Statistical Package for Social Sciences, v18.0 (SPSS Inc., Chicago, IL, USA). Significant differences are marked with alphabet. 


\section{Results and Discussion}

3.1. Variation in the Flux and Distribution of $\mathrm{Ca}^{2+}$ among Different Parts of the Root Tips of P. edulis Seedlings under Drought Stress

The transient net $\mathrm{Ca}^{2+}$ flux was measured from different regions along the root axis using NMT in four different areas, the root apex and root hair zone, including pileorhiza, the meristematic zone, elongation zone, and mature zone (Figure 3a). Responses in the root apex $\mathrm{Ca}^{2+}$ flux are shown in Figure $3 b$. The results showed that there was a significant difference in the ability of P. edulis seedlings to absorb $\mathrm{Ca}^{2+}$ from different parts of the root tip after drought stress. The Figure $3 \mathrm{~b}$ showed the most uptake of $\mathrm{Ca}^{2+}$ in pileorhiza. The pileorhiza was the area with the strongest $\mathrm{Ca}^{2+}$ signal response ability, and the $\mathrm{Ca}^{2+}$ concentration in the root pileorhiza was the highest. The elongation zone was the region with the strongest $\mathrm{Ca}^{2+}$ efflux. The intensity of $\mathrm{Ca}^{2+}$ uptake capacity at different parts of the root tip from strong to weak was: pileorhiza, mature area, meristematic zone, and elongation zone. The Figure $3 c$ shows the fluorescence localization of $P$. edulis root tip cells by laser confocal microscopy. To better observe the distribution of $\mathrm{Ca}^{2+}$ in the pileorhiza, the corresponding heat map is shown in Figure 3d. Combined with Figure 3b, it can be concluded that there were differences in the responsiveness of different parts of the root tip of $P$. edulis to drought stress, which is reflected in both the $\mathrm{Ca}^{2+}$ flux and regional distribution.
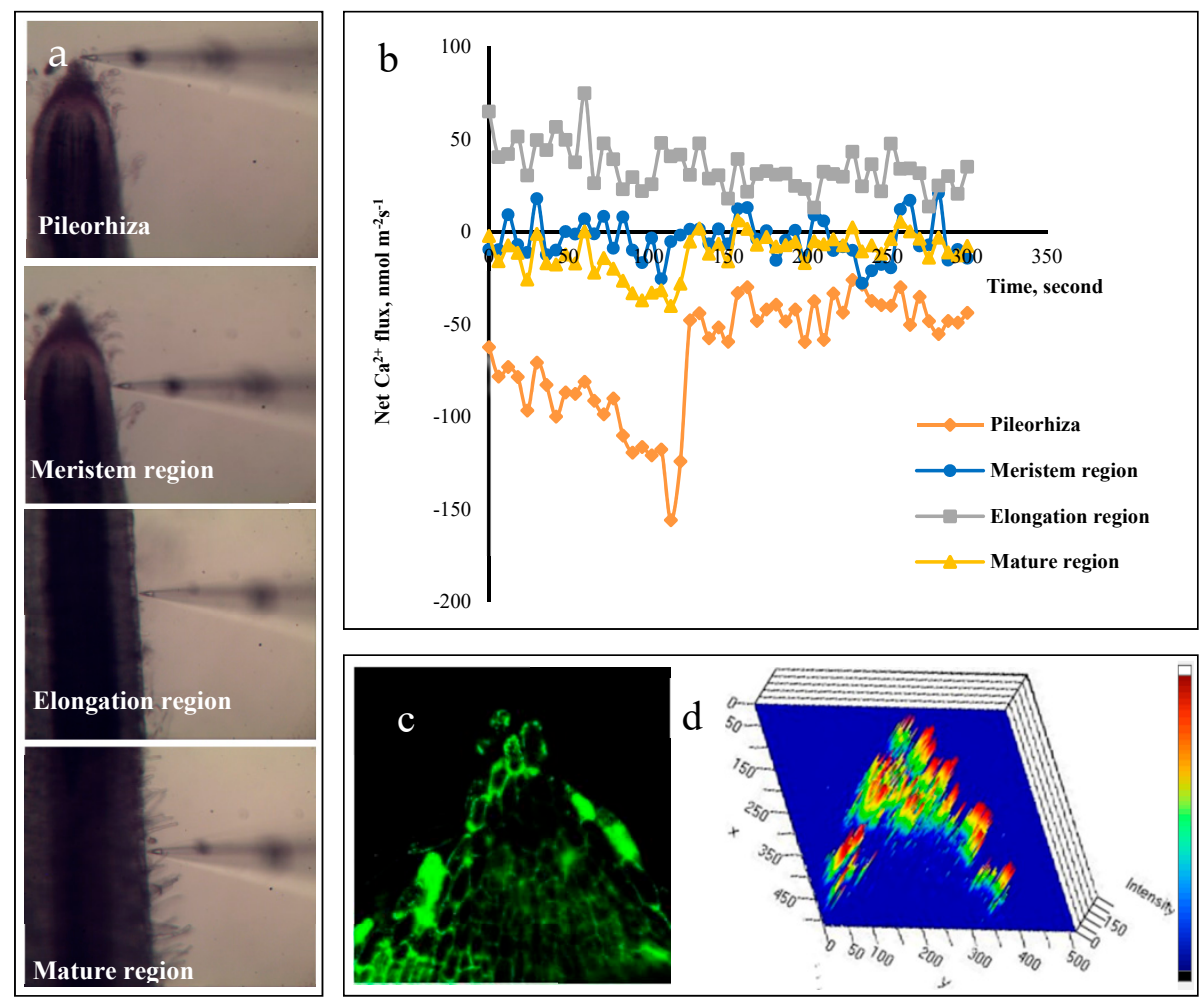

Figure 3. The flux and distribution of $\mathrm{Ca}^{2+}$ in different parts of Phyllostachys edulis root tips under drought stress. $(\mathbf{a}, \mathbf{b}) \mathrm{Net} \mathrm{Ca}^{2+}$ fluxes in different parts of root tip of $P$. edulis seedlings under drought stress induced by $20 \%$ PEG for $10 \mathrm{~min}$. At each position, an average $\mathrm{Ca}^{2+}$ flux was measured for $5 \mathrm{~min}$ before the electrode was repositioned (Data Repetition: 6 replicates). (c) Green fluorescence intensity is positively correlated with the $\mathrm{Ca}^{2+}$ concentration. The $\mathrm{Ca}^{2+}$ fluorescence localization at the root tip of the P. edulis seedlings treated with PEG-simulated drought stress for $10 \mathrm{~min}$. (d) A heat map of a further analysis for (c), which clearly presented that the concentrated distribution of $\mathrm{Ca}^{2+}$ was in the pileorhiza of the P. edulis root tip cells under drought stress. 
We confirmed this difference in the results of Ying [7], which used laser confocal microscopy on fluorescence localization in the root tip. This study showed that $\mathrm{Ca}^{2+}$ absorption intensity in the elongation zone was weakest under drought stress, while Ying's study showed that under drought stress, the $\mathrm{Ca}^{2+}$ in the root tip of P. edulis was mainly distributed in the pileorhiza and elongation zone; the distribution in the meristem area was relatively lower. This was due to the presence of a large number of small vacuoles in the cells of the elongation zone, which were not present in meristem zone. The vacuoles, as a calcium bank in plant cells, may provide a large amount of $\mathrm{Ca}^{2+}$ for P. edulis cytoplasm under drought stress. This leads to a greater concentration of $\mathrm{Ca}^{2+}$ in the elongate zone.

\subsection{Effects of Drought Stress Duration on $\mathrm{Ca}^{2+}$ Absorption Regularity in the Pileorhiza of P. edulis}

Under different durations of PEG-induced drought stress, we observed different conductivity, which represents leaf cell permeability (Figure 4a). An increase in drought stress duration caused electrolyte leakage in the cells, which in turn led to an increase in leaf conductivity. The cell membrane permeability of P. edulis seedlings increased, and there was a positive correlation between time and membrane permeability. The difference in conductivity increase between the 10- and 15-min treatments was higher than that in the $5-10 \mathrm{~min}$ period (difference in conductivity $=15.2 \%$ ). The relative electrical conductivity of $P$. edulis seedlings under drought stress was $40.4 \%$ higher in the 30 -min treatment than in the 15 min treatment. We observed significant correlation between $\mathrm{Ca}^{2+}$ flux and drought stress time $(p<0.01$, Pearson correlation coefficient $(r)=0.967)$ (Figure $4 \mathrm{~b})$. All the flux data in Figure $4 \mathrm{~b}$ represents stable and optimal real-time flux that can respond to $\mathrm{Ca}^{2+}$ concentration in response to drought stress. Relative to the control group, $\mathrm{Ca}^{2+}$ flux in pileorhiza of $P$. edulis seedlings gradually shifted from efflux to influx. Ten minutes of PEG treatment was found to be a "threshold", after which efflux became influx. There was also a positive correlation between leachate conductivity and time as $\mathrm{Ca}^{2+}$ absorption intensity in the pileorhiza $(p<0.01, r=0.976)$, and leaf membrane permeability increased.
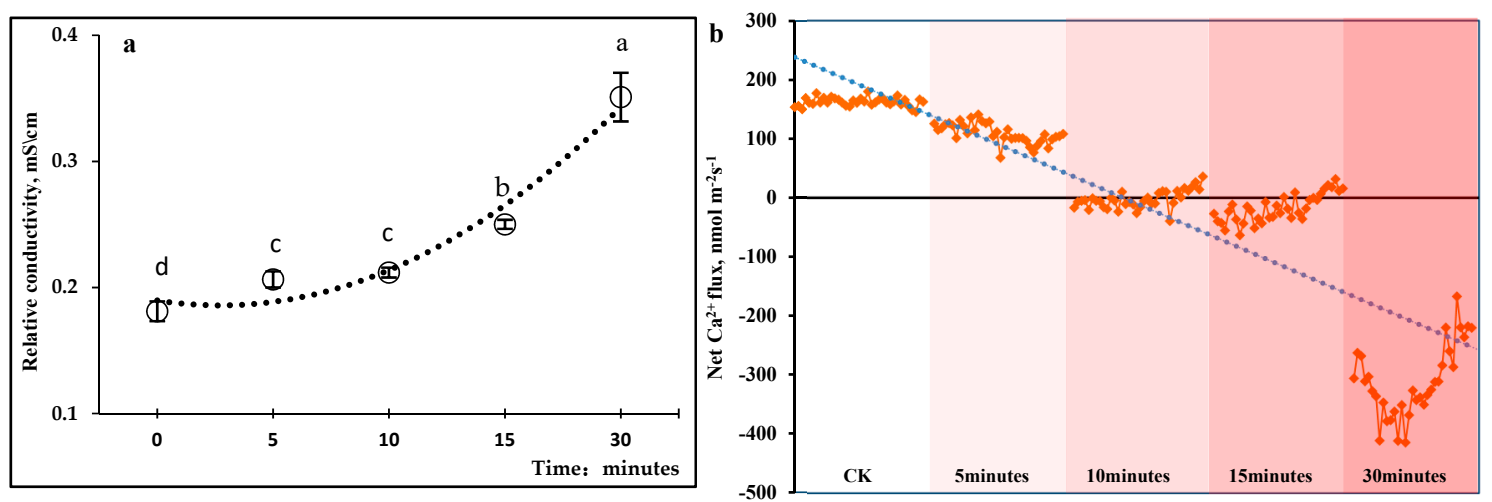

Figure 4. $\mathrm{Ca}^{2+}$ flux of the pileorhiza cells of $P$. edulis seedlings under different durations of PEG-treatment. (a) The relative conductivity of leaves from P. edulis seedlings treated with PEG-simulated drought stress for $5 \mathrm{~min}, 10 \mathrm{~min}, 15 \mathrm{~min}$, and $30 \mathrm{~min}$ (Data Repetition: 6 replicates). The control (CK) is represented by 0 , which was a control group incubated with distilled water. The dashed curve $\left(y=0.0132 x^{2}-0.0406 x+0.2171, R^{2}=0.9615\right)$ represents the linear regression model for relative conductivity and PEG-simulated drought stress. (b) The depth of the red color represents the length of treatment time with $20 \%$ PEG simulating drought stress. From left to right in Figure $4 \mathrm{~b}$ : the CK group, PEG-simulated drought stress treatment for $5 \mathrm{~min}, 10 \mathrm{~min}, 15 \mathrm{~min}$, and $30 \mathrm{~min}$, respectively. The flux data for each treatment in the figures reflected the steady-state real-time flux of maximum response to $\mathrm{Ca}^{2+}$ under drought stress (Data Repetition: 3 replicates); each segment of real-time data comprises flux data for three minutes.

$\mathrm{Ca}^{2+}$ flux in the pileorhiza of $P$. edulis seedlings in the control group (CK) maintained an out-of-range value of approximately $152 \mathrm{nmol} \mathrm{m}^{-2} \mathrm{~s}^{-1}$. Figure 5 showed that $\mathrm{Ca}^{2+}$ flux in the pileorhiza was only slightly changed in the experimental group after 5 min of PEG treatment, indicating that the 
slight degree of drought stress did not significantly induce the stress response leading to $\mathrm{Ca}^{2+}$ signaling in such a short time. When treated with PEG for $30 \mathrm{~min}$, the Figure 5 shows a "V-shaped" pattern of ion uptake, with net flux first increasing and then decreasing. As drought stress time increased, $\mathrm{Ca}^{2+}$ flux gradually returned to control group standard of efflux. It is evident that there is a positive correlation between $\mathrm{Ca}^{2+}$ signal and drought stress time (Figure 5). Under drought stress, there is a "stress threshold" for the $\mathrm{Ca}^{2+}$ signal response. When the stress level reached this threshold, the $\mathrm{Ca}^{2+}$ flux at the pileorhiza underwent significant changes, which may be related to the plant's ability to withstand drought stress.

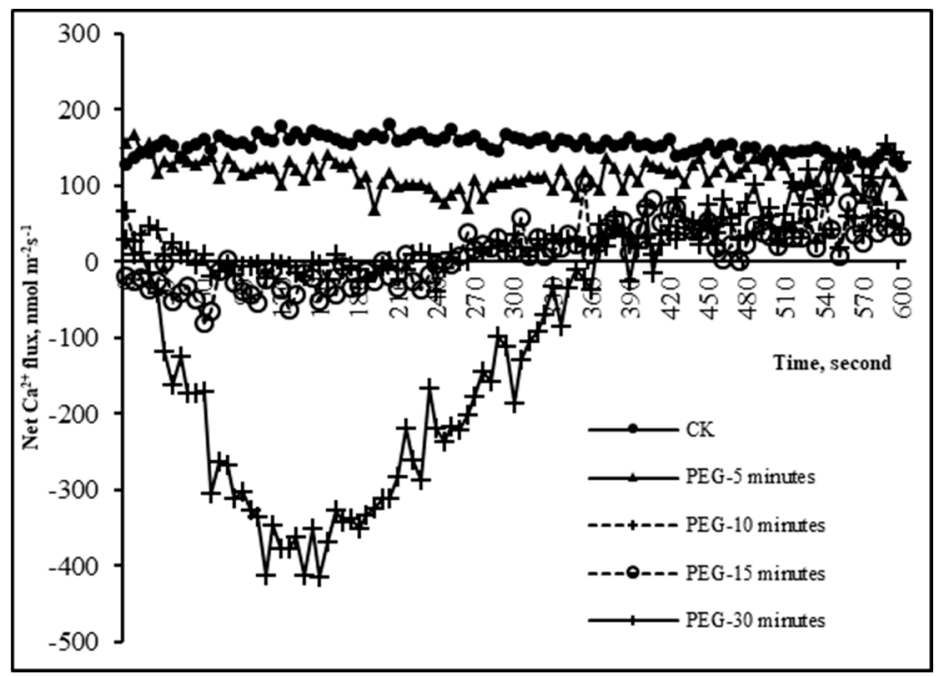

Figure 5. Changes in net $\mathrm{Ca}^{2+}$ flux in the pileorhiza of $P$. edulis seedlings after PEG-induced drought stress. Real-time $\mathrm{Ca}^{2+}$ flux by the pileorhiza of by PEG-induced drought stress for $5 \mathrm{~min}, 10 \mathrm{~min}$, $15 \mathrm{~min}, 30 \mathrm{~min}$, and CK, respectively (Data Repetition: 3 replicates).

Thirty minutes of PEG simulated drought stress showed obvious $\mathrm{Ca}^{2+}$ absorption in the pileorhiza, and $\mathrm{Ca}^{2+}$ flux oscillation increased. With the increase in the duration of drought stress, $\mathrm{Ca}^{2+}$ absorption increased. P. edulis seedlings were able to absorb $\mathrm{Ca}^{2+}$ from the extracellular environment under drought stress conditions, suggesting that while the intracellular calcium stores provide $\mathrm{Ca}^{2+}$ to the cytoplasm, $\mathrm{Ca}^{2+}$ absorbed from extracellular environment was also an important way to accumulate calcium signaling ions in the pileorhiza. It is suggested that $\mathrm{Ca}^{2+}$, as an important signaling molecule in response to drought stress, participated in the transmission of drought signaling to the roots of P. edulis seedlings.

\subsection{Analysis of $\mathrm{Ca}^{2+}$ Signal Transport Patterns in the Pileorhiza of P. edulis under Drought Stress}

The study of the $\mathrm{Ca}^{2+}$ signaling system in plant cells was mainly carried out by pretreatment of experimental materials with $\mathrm{Ca}^{2+}$ signal inhibitors [21]. Regulation of $\mathrm{Ca}^{2+}$ channels is vital. Plasma membrane $\mathrm{Ca}^{2+}$-permeable channels interact with $\mathrm{Ca}^{2+}$ activated nicotinamide adenine dinucleotide phosphate (NADPH) to form a self-amplifying system-a ROS-Ca ${ }^{2+}$ hub [22]. This system could provide the transduction and amplification of the initial $\mathrm{Ca}^{2+}$ or reactive oxygen species (ROS) stimuli into a more sustainable response, with implications for cell growth, hormonal signaling, and stress response [23,24]. To obtain further evidence of the role of plasma membrane $\mathrm{Ca}^{2+}$ channels in $P$. edulis root tips, different $\mathrm{Ca}^{2+}$ inhibitors and ABA were used to further determine the $\mathrm{Ca}^{2+}$ signaling pathways. $\mathrm{Ca}^{2+}$ signal intensity varied with time in the pileorhiza of $P$. edulis seedlings treated with $\mathrm{LaCl}_{3}\left(\mathrm{Ca}^{2+}\right.$ channel blocker), EGTA (extracellular $\mathrm{Ca}^{2+}$ chelating agent), and exogenous ABA.

To determine the factors affecting $\mathrm{Ca}^{2+}$ transport, $\mathrm{Ca}^{2+}$ flux in $P$. edulis root tip treated with a calcium antagonist and ABA was measured using NMT. As shown in Figure $6 \mathrm{a}, \mathrm{LaCl}_{3}$ was applied to the $P$. edulis seedlings treated with PEG-induced drought stress. The $\mathrm{LaCl}_{3}$ treatment significantly 
impeded extracellular $\mathrm{Ca}^{2+}$ influx at the pileorhiza compared to the experimental group without $\mathrm{LaCl}_{3}$. Extracellular $\mathrm{Ca}^{2+}$ channels were involved in $\mathrm{Ca}^{2+}$ fluid transport. The extracellular $\mathrm{Ca}^{2+}$ in seedlings could enter cells through $\mathrm{Ca}^{2+}$ channels under drought stress, which was one of the reasons for the increase of cytoplasmic $\mathrm{Ca}^{2+}$ concentration.
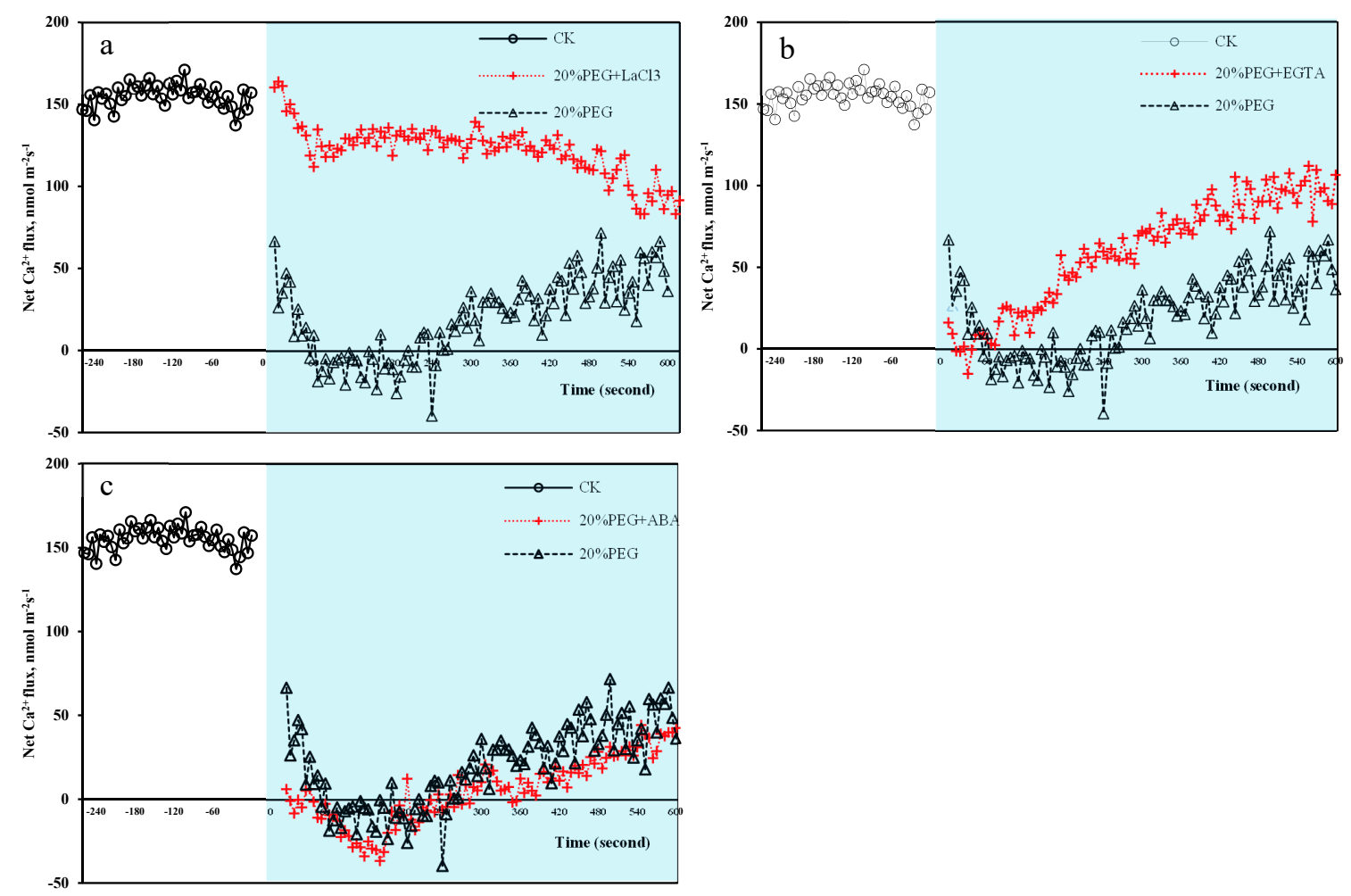

Figure 6. Factor analysis of $\mathrm{Ca}^{2+}$ flux of $P$. edulis seedlings under drought stress (Data Repetition: 3 replicates). The white area represents $\mathrm{Ca}^{2+}$ oscillation in the pileorhiza after treatment of the P. edulis seedlings with distilled water (CK), and the black line graph in the blue area indicates the $\mathrm{Ca}^{2+}$ oscillation in the pileorhiza treated with 20\% PEG-induced drought stress for $10 \mathrm{~min}$. The red line

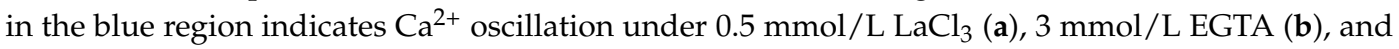
$30 \mu \mathrm{mol} / \mathrm{L} \mathrm{ABA} \mathrm{(c)} \mathrm{in} \mathrm{the} 20 \%$ PEG treatment for $10 \mathrm{~min}$.

In addition, EGTA was used to treat the roots of $P$. edulis seedlings under PEG-simulated drought stress. $\mathrm{Ca}^{2+}$ flux at the pileorhiza was almost always in a state of efflux (Figure 6b), while net $\mathrm{Ca}^{2+}$ flux of without EGTA treatment saw a pattern of "efflux-absorption-efflux". The EGTA-chelating extracellular $\mathrm{Ca}^{2+}$ increased, resulting in decreases of extracellular $\mathrm{Ca}^{2+}$ concentration and a decrease in the ability of pileorhiza to absorb $\mathrm{Ca}^{2+}$; this caused an increase in $\mathrm{Ca}^{2+}$ excretion. $\mathrm{Ca}^{2+}$ uptake in the pileorhiza with the addition of EGTA was significantly lower than in the CK. It is worth noting that treating the pileorhiza with EGTA and $\mathrm{LaCl}_{3}$ while under drought stress had the opposite effects on $\mathrm{Ca}^{2+}$ uptake curves. $\mathrm{Ca}^{2+}$ efflux rate from the pileorhiza of $\mathrm{LaCl}_{3}$ decreased as EGTA treatment increased. $\mathrm{LaCl}_{3}$ treatment hindered the $\mathrm{Ca}^{2+}$ channel in the pileorhiza, which led to a reduction of $\mathrm{Ca}^{2+}$ excretion from the pileorhiza.

Figure $6 \mathrm{c}$ shows $\mathrm{Ca}^{2+}$ absorption in the pileorhiza when treated with $30 \mu \mathrm{mol} / \mathrm{L}$ ABA for 10 min as PEG-induced drought stress treatment. Compared with the control, the ABA treatment showed a smaller oscillation in $\mathrm{Ca}^{2+}$ flux in the pileorhiza, and $\mathrm{Ca}^{2+}$ net flux reflected its strong absorption capacity. Therefore, ABA can promote the increase in $\mathrm{Ca}^{2+}$ absorption intensity in the pileorhiza of P. edulis seedlings. We conclude that ABA may activate the extracellular $\mathrm{Ca}^{2+}$ channel in the pileorhiza and promote $\mathrm{Ca}^{2+}$ uptake (Figure $6 \mathrm{a}, \mathrm{b}$ ). The efflux of ABA-induced $\mathrm{Ca}^{2+}$ spikes remained high among all treatments. These results further confirm that plasma membrane $\mathrm{Ca}^{2+}$ channels activity is involved 
in $\mathrm{Ca}^{2+}$ signaling in PEG-induced drought stress by controlling $\left(\mathrm{Ca}^{2+}\right)$ cyt through $\mathrm{Ca}^{2+}$ influxes. Under drought stress, adding the $\mathrm{Ca}^{2+}$ channel blocker $\mathrm{LaCl}_{3}$ and extracellular $\mathrm{Ca}^{2+}$ chelating agent EGTA could significantly inhibit extracellular $\mathrm{Ca}^{2+}$ influx. Exogenous application of ABA could increase the ability of the pileorhiza to absorb $\mathrm{Ca}^{2+}$.

\subsection{Analysis of $\mathrm{Ca}^{2+}$ Signaling Pathway in Leaves under Drought Stress}

In addition to chemical signal root transduction, drought stress triggered $\mathrm{Ca}^{2+}$ movement in leaf cells. $\mathrm{Ca}^{2+}$ may regulate leaf stomatal movement to control transpiration and respiration, as a self-protection and adaption measure in response to environmental stress. To simultaneously monitor cell-specific $\mathrm{Ca}^{2+}$ P. edulis seedling leaves, we used a confocal microscope to record $\mathrm{Ca}^{2+}$ fluorescence localization (Figure 7).



Figure 7. Localization of cellular $\mathrm{Ca}^{2+}$ dynamics in leaves of $P$. edulis seedlings. Calcium-fluorescence localization of the leaves of the P. edulis seedlings under drought stress for $5 \mathrm{~min}, 15 \mathrm{~min}$, and $30 \mathrm{~min}$ induced by $20 \%$ PEG, respectively. The green fluorescence intensity represents the $\mathrm{Ca}^{2+}$ concentration and is positively correlated with the $\mathrm{Ca}^{2+}$ concentration.

$\mathrm{CK}$ is the $\mathrm{Ca}^{2+}$ fluorescence map of the lower epidermal cells treated with distilled water. Under normal water conditions, $\mathrm{Ca}^{2+}$ was mainly localized within the cell walls of guard cells, accessory cells, and long cells in P. edulis seedling leaves. $\mathrm{Ca}^{2+}$ was less commonly found to be distributed in the cytoplasm. As drought stress duration increased, $\mathrm{Ca}^{2+}$ concentration in the cytoplasm increased, except for in tethered cells. Among them, $\mathrm{Ca}^{2+}$ in long cells and guard cells increased significantly. The fluorescence intensity in the cytoplasm was also higher than that of the CK. Fluorescence intensity in the cytoplasm of accessory cells did not significantly increase. There were particularly pronounced differences in $\mathrm{Ca}^{2+}$ distribution in the 30 min PEG treatment. In addition to in tethered cells, the cytoplasmic fluorescence in all living cells, including guard cells, increased. Our results suggest that $\mathrm{Ca}^{2+}$ signals in response to PEG stress reflect distinct cellular $\mathrm{Ca}^{2+}$ dynamics.

With increased duration of drought stress, the fluorescence intensity in the cytoplasm of long cells increased. Only when a certain degree of drought stress was reached would $\mathrm{Ca}^{2+}$ in the cytoplasm of leaf guard cells escape from the cell wall and diffuse into the cytoplasm, resulting in a significant increase in the fluorescence intensity of the cytoplasm. In comparison, the $\mathrm{Ca}^{2+}$ in the cytoplasm of accessory cells was not obviously enhanced. To further verify that $\mathrm{Ca}^{2+}$ in the leaf cells of $P$. edulis was also transmitted through the cytoplasmic $\mathrm{Ca}^{2+}$ channels, three $\mathrm{Ca}^{2+}$ inhibitors were used to treat the 
seedlings under drought conditions. $\mathrm{Ca}^{2+}$ fluorescence localization under these conditions is shown in Figure 8 .

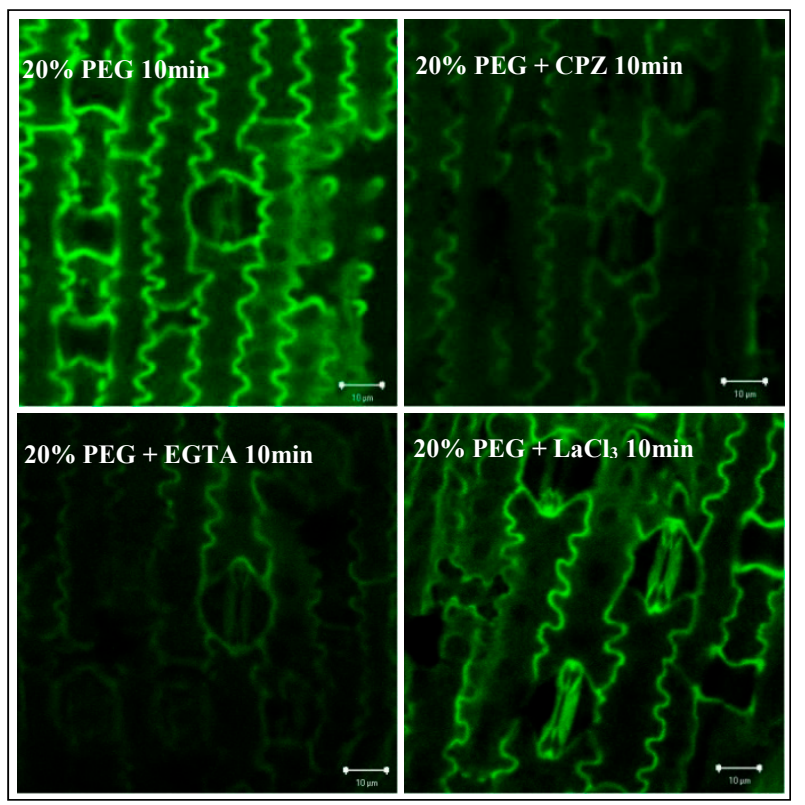

Figure 8. Localization of cellular $\mathrm{Ca}^{2+}$ dynamics in leaves of $P$. edulis seedlings treated with different $\mathrm{Ca}^{2+}$ inhibitors and drought stress. $\mathrm{Ca}^{2+}$ fluorescence localization in leaves of plants treated with $20 \%$ PEG-induced drought stress and $0.1 \mathrm{mmol} / \mathrm{L} \mathrm{CPZ,} 3 \mathrm{mmol} / \mathrm{L} \mathrm{EGTA}$, or $0.5 \mathrm{mmol} / \mathrm{L} \mathrm{LaCl}_{3}$ for $10 \mathrm{~min}$.

To confirm the effect of calcium channels on $\mathrm{Ca}^{2+}$, we analyzed the $\mathrm{Ca}^{2+}$ fluorescence under three $\mathrm{Ca}^{2+}$ inhibitor treatments. The addition of $\mathrm{CPZ}$ inhibited the binding of $\mathrm{Ca}^{2+}$ to CAM in the seedlings; thus, the $\mathrm{Ca}^{2+}$ signal was not transmitted further. The results showed that after treatment with $0.1 \mathrm{mmol} / \mathrm{L} \mathrm{CPZ}$ in the seedlings under PEG-simulated drought stress for $10 \mathrm{~min}$, the brightness of the fluorescence in the cell wall and cytoplasm of the leaf cells was less than under the treatment without CPZ. Under drought stress, the $\mathrm{Ca}^{2+}$ in leaf cells of the P. edulis seedlings treated with $0.1 \mathrm{mmol} / \mathrm{L}$ CPZ were mainly distributed in the cell wall. The fluorescence brightness in the cell wall decreased more obviously than in other parts of the leaf.

We analyzed the distribution of $\mathrm{Ca}^{2+}$ in leaves treated with $3 \mathrm{mmol} / \mathrm{L}$ EGTA. Fluorescence intensity in the cell wall and cytoplasm reduced, indicating that $\mathrm{Ca}^{2+}$ concentration in the cell wall and cytoplasm decreased compared with the control group. This indicates that P. edulis seedling leaves can still take up $\mathrm{Ca}^{2+}$ from extracellular pathways under drought stress to produce calcium signals. Extracellular $\mathrm{Ca}^{2+}$ was chelated in the leaves under EGTA treatment, resulting in a decrease in extracellular $\mathrm{Ca}^{2+}$ uptake.

Treatment with $\mathrm{LaCl}_{3}$ prevents $\mathrm{Ca}^{2+}$ from extracellular entry, and $\mathrm{Ca}^{2+}$ in the cytoplasm of leaf cells significantly reduced. $\mathrm{Ca}^{2+}$ was mainly concentrated in the cell walls in this treatment (Figure 8). The results of $\mathrm{Ca}^{2+}$ fluorescence localization in leaf cells after treatment with $0.5 \mathrm{mmol} / \mathrm{L} \mathrm{LaCl} \mathrm{for}_{3}$ 10 min in drought-stressed $P$. edulis seedlings showed a decrease in $\mathrm{Ca}^{2+}$ fluorescence intensity in the cytoplasm of the cells. This was caused by the $\mathrm{LaCl}_{3}$ blocking the cytoplasmic $\mathrm{Ca}^{2+}$ channel, blocking extracellular $\mathrm{Ca}^{2+}$ entry through the cell wall. This shows that $\mathrm{Ca}^{2+}$ in the leaves of P. edulis can be transported through $\mathrm{Ca}^{2+}$ channels of the plasma membrane, absorbing $\mathrm{Ca}^{2+}$ from outside the cell, and using the potential difference to generate calcium signals.

\subsection{Analysis of the Effects of $\mathrm{Ca}^{2+}$ Signals on $\mathrm{H}_{2} \mathrm{O}_{2}$ and $A B A$ Signaling Pathways under Drought Stress}

The $\mathrm{H}_{2} \mathrm{O}_{2}$ fluorescence localization map of $P$. edulis leaves is shown in Figure $9 . \mathrm{H}_{2} \mathrm{O}_{2}$ concentration in the leaf cytoplasm increased with drought stress time (Figure 9a). P. edulis seedling 
leaves treated with different $\mathrm{Ca}^{2+}$ inhibitors under PEG-simulated drought stress were subjected to laser confocal technology for $\mathrm{H}_{2} \mathrm{O}_{2}$ fluorescence localization to study the relationship between $\mathrm{Ca}^{2+}$ signaling and $\mathrm{H}_{2} \mathrm{O}_{2}$ in the stress signaling pathway (Figure $9 \mathrm{~b}$ ). Compared with $\mathrm{CK}$, plants treated with $0.1 \mathrm{mmol} / \mathrm{L} \mathrm{CPZ}$ showed lower leaf fluorescence, indicating that $\mathrm{CPZ}$ could also prevent $\mathrm{H}_{2} \mathrm{O}_{2}$ signal transduction. The calcium signals were unable to be transmitted normally, resulting in the decrease of $\mathrm{H}_{2} \mathrm{O}_{2}$ in the leaf cells. This indicates that the regulation of $\mathrm{H}_{2} \mathrm{O}_{2}$ activity requires the participation of $\mathrm{Ca}^{2+}$. Both $0.5 \mathrm{mmol} / \mathrm{L} \mathrm{LaCl}_{3}$ and $3 \mathrm{mmol} / \mathrm{L}$ EGTA inhibited the production of $\mathrm{H}_{2} \mathrm{O}_{2}$ in guard cells, accessory cells, and long cells in leaves of $P$. edulis seedlings under drought stress. It is inferred that the $\mathrm{Ca}^{2+}$ signal is generated upstream of the active oxygen signal in the drought stress signaling network of P. edulis, and that $\mathrm{H}_{2} \mathrm{O}_{2}$ activity in leaf cells requires $\mathrm{Ca}^{2+}$ participation.

$\mathbf{a}$

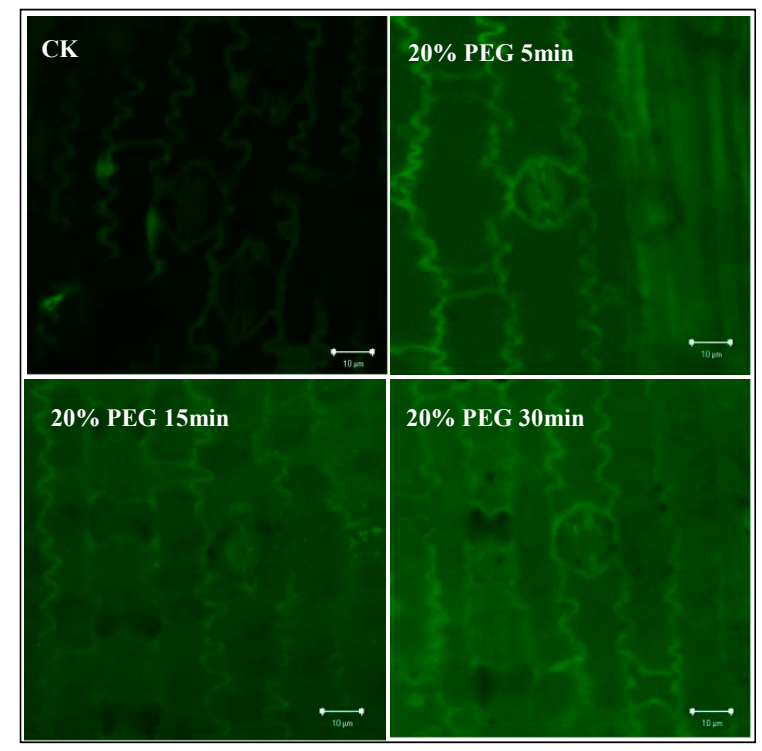

b

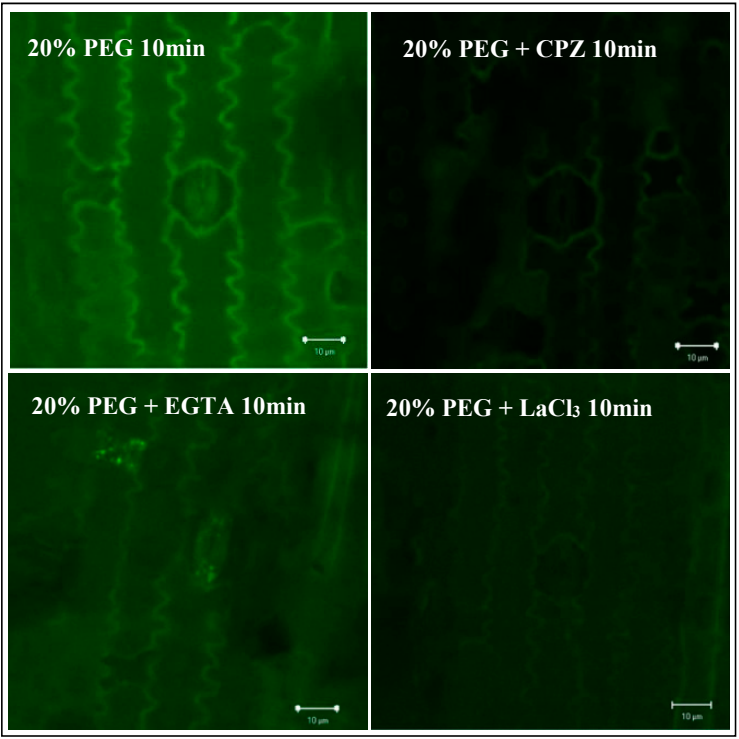

Figure 9. $\mathrm{H}_{2} \mathrm{O}_{2}$ fluorescence in P. edulis seedling leaves under drought stress. The green fluorescence intensity in the figure represents concentration of hydrogen peroxide, with more fluorescence indicating a higher concentration of $\mathrm{H}_{2} \mathrm{O}_{2}$. (a) $\mathrm{H}_{2} \mathrm{O}_{2}$ fluorescence localization at different treatment times $(5 \mathrm{~min}$, $15 \mathrm{~min}$, and $30 \mathrm{~min}$ ) using 20\% PEG-induced drought stress. (b) The samples were treated with different $\mathrm{Ca}^{2+}$ inhibitors (CPZ, EGTA, and $\mathrm{LaCl}_{3}$ ) for 10 min under 20\% PEG-induced drought stress.

Laser confocal microscopy was used to detect the $\mathrm{Ca}^{2+}$ and $\mathrm{H}_{2} \mathrm{O}_{2}$ fluorescence signal in living leaf cells. The results indicated that the exogenous application of ABA under drought stress led to an increase in the concentration of $\mathrm{Ca}^{2+}$ and $\mathrm{H}_{2} \mathrm{O}_{2}$ in the mesophyll cells of $P$. edulis seedlings. Interestingly, there was a positive correlation between $\mathrm{Ca}^{2+}$ and $\mathrm{H}_{2} \mathrm{O}_{2}$ dynamics. ABA might activate $\mathrm{Ca}^{2+}$ channels of the plasma membrane and promote the production of $\mathrm{Ca}^{2+}$ signals in the pileorhiza of $P$. edulis seedlings.

$\mathrm{H}_{2} \mathrm{O}_{2}$ fluorescence intensity in guard cells was significantly higher in the ABA-treated group than in the group not treated with ABA (Figure 10). In plants, ABA is involved in many stress responses [25-27]. Regulatory systems of reactive oxygen species (ROS) are known to be integrated with other pathways involving $\mathrm{Ca}^{2+}$ signaling, protein kinases, and hormones pathways to regulate the defense mechanism in plants [28]. The existence of ABA-induced genes, which are expressed in stomatal guard cells, allows us to closely examine the role of $\mathrm{Ca}^{2+}$ [29]. In rice, the $\mathrm{Ca}^{2+} / \mathrm{CaM}$-dependent protein kinase OsDMI3 has been shown to be required for ABA-induced antioxidant defense [30]. These results demonstrated that ABA also plays a key role in the signal transduction of $\mathrm{Ca}^{2+}$ in the signaling network of the leaves of $P$. edulis treated with drought stress. $\mathrm{Ca}^{2+}$ not only acted as the upstream signal of $\mathrm{H}_{2} \mathrm{O}_{2}$, but was also involved in the signal transduction process of $A B A$. ABA could promote the production of $\mathrm{Ca}^{2+}$ signaling in leaves and stimulate the burst 
of $\mathrm{H}_{2} \mathrm{O}_{2}$, a reactive oxygen species, in the guard cells. P. edulis may enhance drought tolerance via ABA-induced stomatal closure by ROS production.

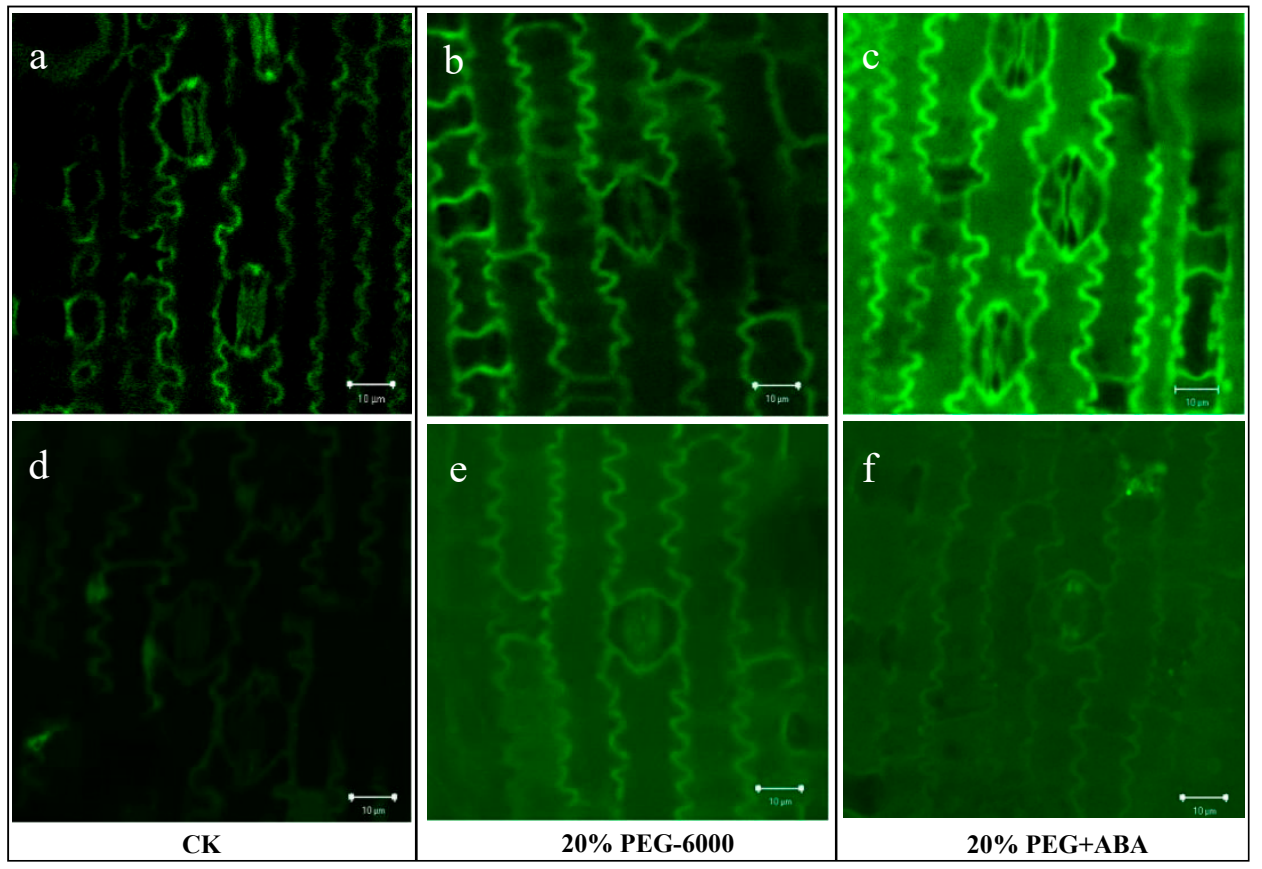

Figure 10. Localization of fluorescence of $\mathrm{Ca}^{2+}$ and $\mathrm{H}_{2} \mathrm{O}_{2}$ in mesophyll cells after application of exogenous ABA under drought stress. (a) Calcium-fluorescence localization of leaves of $P$. edulis seedlings with distilled water. (b) Calcium-fluorescence localization of leaves of $P$. edulis seedlings under 20\% PEG 6000-induced stress for $10 \mathrm{~min}$. (c) Calcium-fluorescence localization of leaves of P. edulis seedlings with the application of $30 \mu \mathrm{mol} / \mathrm{L} \mathrm{ABA}$ to $20 \%$ PEG-induced stress for $10 \mathrm{~min}$. (d-f) $\mathrm{H}_{2} \mathrm{O}_{2}$ fluorescence localization under the same treatment as above.

\section{Conclusions}

This study indicated that the conductivity of $P$. edulis leaves increased with the degree of drought stress induced. $\mathrm{Ca}^{2+}$ is an important signaling molecule in response to drought stress in the root tip of P. edulis, especially in the transmission of stress signals and resistance to drought stress. Under drought stress, root tip cells of $P$. edulis can be used to transport $\mathrm{Ca}^{2+}$ from the extracellular environment to the cytoplasm, $\mathrm{Ca}^{2+}$ channels participate in extracellular $\mathrm{Ca}^{2+}$ transportation, and ABA may activate $\mathrm{Ca}^{2+}$ channels in the plasma membrane and promote $\mathrm{Ca}^{2+}$ signal production in the pileorhiza of P. edulis. In P. edulis leaves, $\mathrm{Ca}^{2+}$ can also be transported through the $\mathrm{Ca}^{2+}$ channels of the plasma membrane under drought stress, absorbing $\mathrm{Ca}^{2+}$ from outside the cell and generating $\mathrm{Ca}^{2+}$ signals through potential difference. The responsiveness of $\mathrm{Ca}^{2+}$ signals to drought stress in leaves of $P$. edulis from strong to weak was shown as follows: (1) long cells; (2) guard cells; (3) accessory cells; and (4) plug cells. $\mathrm{Ca}^{2+}$ acts as the upstream signal of $\mathrm{H}_{2} \mathrm{O}_{2}$ in the signal network of the mesophyll cells of the $P$. edulis under drought stress. It is also involved in ABA signal transduction process. ABA could promote $\mathrm{Ca}^{2+}$ signal production and stimulate $\mathrm{H}_{2} \mathrm{O}_{2}$ bursts in P. edulis leaves.

This study provides a method for the spatial and temporal localization of $\mathrm{Ca}^{2+}$ signaling and flux in P. edulis. Further research on $\mathrm{Ca}^{2+}$ signaling is essential, as it may help shed light on the physiology of $P$. edulis under stress. There are also areas for improvement in this study. The first is that processing the mesophyll samples may damage the cells or put them under stress conditions, thus affecting the $\mathrm{Ca}^{2+}$ fluorescence of the leaves under the laser confocal microscope. Autofluorescence of lignin can also have an effect on $\mathrm{Ca}^{2+}$ fluorescence. It is particularly important to improve this methodology in the future. 
Author Contributions: X.J., C.C., and S.F. conceived and designed the experiments; X.J. performed the experiments; X.J. analyzed the data; L.W. and X.Z. contributed reagents/materials/analysis tools; X.J. wrote the paper, and C.C. revised it.

Funding: This research was funded by the International Centre for Bamboo and Rattan Center. Effects of Drought Stress on Water Physiology and Productivity of Phyllostachys edulis (grant number 1632018008).

Acknowledgments: The authors acknowledge the financial supports of the Foundation of International Centre for Bamboo and Rattan (No. 1632018008).

Conflicts of Interest: The authors declare no conflict of interest.

\section{References}

1. Hepler, P.K. Calcium: A central regulator of plant growth and development. Plant. Cell 2005, 17, $2142-2155$. [CrossRef] [PubMed]

2. Reddy, A.S.N.; Ali, G.S.; Celesnik, H.; Day, I.S. Coping with stresses: Roles of calcium-and calcium/calmodulin-regulated gene expression. Plant. Cell 2011, 23, 2010-2032. [CrossRef] [PubMed]

3. Reddy, A.S.N. Calcium: Silver bullet in signaling. Plant Sci. 2001, 160, 381-404. [CrossRef]

4. Michard, E. Glutamate receptor-like genes form $\mathrm{Ca}^{2+}$ channels in pollen tubes and are regulated by pistil D-serine. Science 2011, 332, 434-437. [CrossRef] [PubMed]

5. Miedema, H.; Bothwell, J.H.F.; Brownlee, C.; Davies, J.M. Calcium uptake by plant cells-channels and pumps acting in concert. Trends Plant. Sci. 2001, 6, 514-519. [CrossRef]

6. Jiang, Q. Effect of calcium ions in the process of responses of Phyllostachys edulis. Master's Thesis, Zhejiang A. \& F. University, Hangzhou, China, 2012.

7. Ying, Y.Q.; Du, X.H.; Jiang, Q.; Xu, C.M.; Wu, J.S. Distribution of $\mathrm{Ca}^{2+}$ at the Tip of Phyllostachys edulis Root under Drought Stress and Physiological Functions of Exogenous $\mathrm{Ca}^{2+}$. Scientia Silvae Sinicae 2013, 49, 141-146.

8. Wilkins, K.A.; Elsa, M.; Swarbreck, S.M.; Davies, J.D. Calcium-Mediated Abiotic Stress Signaling in Roots. Front. Plant Sci. 2016, 7, 1269. [CrossRef] [PubMed]

9. Li, F.; Zhang, H.; Liu, L.; Guo, L.L.; Wang, L.S.; Zheng, Y.P. Effects of Exogenous $\mathrm{Ca}^{2+}$ on Stomatal Traits and Gas Exchange Parameters of Anthurium scherzerianum. North. Hortic. 2017, 8, 80-85.

10. Edel, K.H.; Marchadier, E.; Brownlee, C.; Kudla, J.; Hetherington, A.M. The Evolution of Calcium-Based Signalling in Plants. Curr. Biology 2017, 27, 667-679. [CrossRef] [PubMed]

11. Yuan, P.; Jauregui, E.; Du, L.; Tanaka, K. Calcium signatures and signaling events orchestrate plant-microbe interactions. Curr. Opin. Plant. Biology 2017, 38, 173-183. [CrossRef] [PubMed]

12. Knight, H.; Trewavas, A.J.; Knight, M.R. Calcium signalling in Arabidopsis thaliana responding to drought and salinity. Plant. J. 1997, 12, 1067. [CrossRef] [PubMed]

13. Shinozaki, K.; Shinozaki, Y. Gene Expression and Signal Transduction in Water-Stress Response. Plant. Physiol. 1997, 115, 327-334. [CrossRef] [PubMed]

14. Tamás, L.; Mistrík, I.; Huttová, J.; Haluskova, L.; Valentovicova, K.; Zelinova, V. Role of reactive oxygen species-generating enzymes and hydrogen peroxide during cadmium, mercury and osmotic stresses in barley root tip. Planta 2010, 231, 221-231. [CrossRef] [PubMed]

15. Oracz, K.; Elmaaroufbouteau, H.; Kranner, I.; Bogatek, R.; Corbineau, F.; Bailly, C. The mechanisms involved in seed dormancy alleviation by hydrogen cyanide unravel the role of reactive oxygen species as key factors of cellular signaling during germination. Plant. Physiol. 2009, 150, 494-505. [CrossRef] [PubMed]

16. Yoshioka, H.; Asai, S.; Yoshioka, M.; Kobayashi, M. Molecular mechanisms of generation for nitric oxide and reactive oxygen species, and role of the radical burst in plant immunity. Mol. Cell 2009, 28, 321-329. [CrossRef] [PubMed]

17. Kwak, J.M.; Mori, I.C.; Pei, Z.M.; Leonhardt, N.; Torres, M.A.; Dangl, J.L.; Bloom, R.E.; Bodde, S.; Jones, J.D.G.; Schroeder, J.I. NADPH oxidase AtrbohD and AtrbohF genes function in ROS-dependent ABA signaling in Arabidopsis. EMBO J. 2003, 22, 2623-2633. [CrossRef] [PubMed]

18. Sha, Q.; Jiang, M.Y.; Lin, F.; Wang, J.X. The expression of calmodulin genes induced by water stress is associated with ABA and $\mathrm{H}_{2} \mathrm{O}_{2}$. J. Nanjing Agric. Univ. 2009, 3, 52-57.

19. Antoine, A.F.; Faure, J.E.; Dumas, C.; Feijo, J.A. Differential contribution of cytoplasmic $\mathrm{Ca}^{2+}$ and $\mathrm{Ca}^{2+}$ influx to gamete fusion and egg activation in maize. Nat. Cell Biology 2001, 3, 1120-1123. [CrossRef] [PubMed] 
20. Zhu, X.; Taylor, A.; Zhang, S.; Zhang, D.; Feng, Y.; Liang, G. Measuring spatial and temporal Ca ${ }^{2+}$ signals in Arabidopsis plants. J. Vis. Exp. 2015, 91,1-13.

21. Lu, Y. The Analysis of Calcium Signal Characteristics and Its Effect on Phyllostachys edulis Seeding under Drought Stress. Master's Thesis, Zhejiang A. \& F. University, Hangzhou, China, 2014.

22. Gelli, A.; Higgins, V.J.; Blumwald, E. Activation of Plant Plasma Membrane Ca ${ }^{2+}$-Permeable Channels by Race-Specific Fungal Elicitors. Plant. Physiol. 1997, 113, 269-279. [CrossRef] [PubMed]

23. Demidchik, V.; Shabala, S.; Isayenkov, S.; Cuin, T.A.; Pottosin, I. Calcium transport across plant membranes: Mechanisms and functions. New Phytol. 2018, 220, 49-69. [CrossRef] [PubMed]

24. Zhu, J.K. Salt and drought stress signal transduction in plants. Annu. Rev. Plant. Biol. 2002, 53, $247-273$. [CrossRef] [PubMed]

25. Tuteja, N.; Sopory, S.K. Chemical signaling under abiotic stress environment in plants. Plant. Signal. Behav. 2008, 3, 525-536. [CrossRef] [PubMed]

26. Alqurashi, M.; Thomas, L.; Gehring, C.; Marondedze, C. A Microsomal Proteomics View of $\mathrm{H}_{2} \mathrm{O}_{2}-$ and ABA-Dependent Responses. Proteome 2017, 5, 22. [CrossRef] [PubMed]

27. Hetherington, A.M. Guard cell signaling. Cell 2001, 107, 711-714. [CrossRef]

28. Suzuki, N.; Katano, K. Coordination Between ROS Regulatory Systems and Other Pathways Under Heat Stress and Pathogen Attack. Front. Plant. Sci. 2018, 9, 490. [CrossRef] [PubMed]

29. Taylor, J.E.; Renwick, K.F.; Webb, A.A.R.; McAinsh, M.R.; Furini, A. ABA-regulated promoter activity in stomatal guard cells. Plant. J. 1995, 7, 129-134. [CrossRef] [PubMed]

30. Huang, L.; Zhang, M.; Jia, J.; Zhao, X.; Huang, X.; Ji, E.; Ni, L.; Jiang, M. An Atypical Late Embryogenesis Abundant Protein OsLEA5 Plays A Positive Role in ABA-Induced Antioxidant Defense in Oryza sativa L. Plant. Cell Physiol. 2018, 59, 916-929. [CrossRef] [PubMed]

(C) 2019 by the authors. Licensee MDPI, Basel, Switzerland. This article is an open access article distributed under the terms and conditions of the Creative Commons Attribution (CC BY) license (http:/ / creativecommons.org/licenses/by/4.0/). 